This item was submitted to Loughborough's Research Repository by the author.

Items in Figshare are protected by copyright, with all rights reserved, unless otherwise indicated.

\title{
Determinants of the informal economy of an emerging economy: a multiple indicator, multiple causes approach
}

PLEASE CITE THE PUBLISHED VERSION

http://dx.doi.org/10.1504/IJESB.2016.076643

\section{PUBLISHER}

(C) Inderscience

\section{VERSION}

AM (Accepted Manuscript)

\section{PUBLISHER STATEMENT}

This work is made available according to the conditions of the Creative Commons Attribution-NonCommercialNoDerivatives 4.0 International (CC BY-NC-ND 4.0) licence. Full details of this licence are available at: https://creativecommons.org/licenses/by-nc-nd/4.0/

\section{LICENCE}

CC BY-NC-ND 4.0

\section{REPOSITORY RECORD}

Igudia, Eghosa, Rob Ackrill, Simeon Coleman, and Carlyn Dobson. 2019. "Determinants of the Informal Economy of an Emerging Economy: A Multiple Indicator, Multiple Causes Approach". figshare. https://hdl.handle.net/2134/22864. 
Title: Determinants of the informal economy of an emerging economy: a multiple indicator, multiple causes (MIMIC) approach.

\author{
Eghosa Igudia $^{1} * *, \#$, Rob Ackrill^${ }^{\wedge}$, Simeon Coleman $^{+}$, Carlyn Dobson $^{\&}$ \\ ** Northampton Business School, The University of Northampton; ${ }^{\wedge}$ Nottingham Business \\ School, Nottingham Trent University; ${ }^{+}$School of Business and Economics, Loughborough \\ University; ${ }^{\&}$ Hull University Business School, University of Hull.
}

\begin{abstract}
Positing the implementation of evidenced-based policies to manage the informal economy, our paper employs, in a novel way, the multiple-cause, multiple-indicator model and primary data, to identify the determinants of the Nigerian informal economy. Building on previous literature, relevant determinants of the informal economy were constructed from participants' responses to questions designed to solicit such information. We found the factors responsible for the origin and expansion of the Nigerian informal economy to include: unemployment, a need to be autonomous/self-employed, corruption of government officials/agencies, participants' desire to pay less tax, and participants' need to survive. The greatest influence, in terms of magnitude and impacts, comes from the 'participants' need to survive' factor, followed by corruption. Our policy recommendations follow these identified factors, and recognise the positive and important role played by the informal economy. Although country-specific, our findings/recommendations may be used to inform policy in other countries with similar economic structures as Nigeria.
\end{abstract}

Keywords: Determinants of the informal economy, Nigeria, MIMIC approach, Informal sector policies.

Introduction

In recent years, the size of the informal economy has expanded globally (Schneider et al., 2010). This has generated increasing debates about the best way to manage the sector. In this study, we assert that the informal economy will best be managed if policies implemented are evidence-based. This underscores the need to examine, in detail, a country's specific factors that (potentially) can influence the expansion of the informal economy. In this paper, the focus will be on the Nigerian informal economy. Nigeria, with a population of over 168 million people, is the most populous country in Africa (World Bank, 2013). Moreover, following the rebasing of its Gross Domestic Product (GDP) in 2014, it became the largest economy in Africa and $26^{\text {th }}$ largest economy globally (Onuba and Abioye, 2014). Its 2013 rebased nominal GDP was US\$510bn (ibid). The implication of this is that whatever the size of the informal economy relative to the formal economy in Nigeria, its absolute size is likely to be substantial. As a result, it is likely to play an extremely important economic and social role. Thus there is a need to ensure policies which affect the informal economy do so to

\footnotetext{
${ }^{\#}$ Corresponding author; Email: eghosa.igudia@ northampton.ac.uk; Tel: +44(0)1604892197
} 
maximise the overall positive impact on the Nigerian economy. Indeed, given its size, Nigeria's informal economy has an importance that extends beyond the country itself.

Previous Nigerian government policies, particularly the government implementation of a structural adjustment program (SAP) in the 1980s, have tended to trigger an expansion of the country's informal economy (Verick, 2006). It is the need to have an empirical study which streamlines policy-recommendations for the informal economy in Nigeria, and further, to identify possible lessons for other countries, which gives an overwhelming justification for this study.

In this paper, we define the informal economy as consisting of three elements: informal employment (i.e. those doing informal types job, regardless of the location or enterprise of operation); employment in the informal economy (i.e., those working in informal sector enterprises, regardless of the type of job done); and all legal activities that contribute to GDP but which are not captured by official statistics, for various reasons. These factors/determinants (discussed below) either cause, or reinforce, an expansion in the size of the informal economy.

The remainder of the paper is structured as follows, Section 2 reviews relevant literature, whilst Section 3 discusses methods. Then, results are presented and discussed in Section 4, and Section 5 concludes.

\subsection{Literature review}

Over the years the informal economy, as a concept, has been used to describe different economic conditions. It was initially thought to be a characteristic of developing countries, but there is now a consensus that economic activities are undertaken in the informal sector in all countries, and in various forms (Becker, 2004). These different views, as well as factors responsible for the (origin and) prevalence of the informal economy have been theorised in the literature. While the main theories (Dualist or Modernist, Structuralists, Legalist or Neoliberals, and Voluntarist or Post-structuralist theories) present their different views on why individuals/firms carry out their activities in the informal economy, there are some overlaps in their propositions. We now turn briefly to discuss these main theories.

The early view of the informal economy is explained within the precincts of Dualism or Modernisation theory. Defined variously as traditional and modern sectors (Boeke, 1953), firm-centred and bazaar-type economies (Geertz, 1963), upper and lower circuits (Santos, 1973), modern and traditional economies (Sethuraman, 1976), and high and low income sectors (Sethuraman, 1981), Dualism/Modernisation theory describes two distinct economies in which relative advantages exist in one (the formal) over the other (the informal economy). In addition, this theory argues that the informal economy exists to provide income or a safety net for the poor (ILO, 1972; Becker, 2004), represents a systemic flaw in, and shows the failure of, the economic model of a country (Bureau and Fendt, 2011), but it (the informal economy) will cease to exist once development and modernisation sets-in (Becker, 2004). 
Evidence of economic failure can manifest itself through a mismatch between growth in the population and in modern industrial employment, and between people's skills and the structure of modern employment opportunities, as well as a country's high level of corruption, underdevelopment, lack of growth of the formal economy, and inadequate jobs for the existing workforce. All of these can contribute to an expansion in the size of the informal economy (ILO, 1972; Sethuraman, 1988; Bureau and Fendt, 2011; Chen, 2012).

In contrast to Dualism, the Structuralist theory, popularised by Moser (1978) and Castells and Portes (1989), argues that the formal and informal economies are interconnected and interdependent. Additionally, the informal economy is seen as an offshoot of capitalism (Henry 1978; Chen, 2012), as a result of the structured development within the capitalist mode of production, the 'deregulated global economy', and economies' 'under-regulation' (Williams 2013: 263). Under this view, firms operate in the informal economy in order to increase their ability to compete, reduce the power of labour unions and labour costs, avoid or further limit state regulations, and respond to global competition and industrialisation. This has led to the setting up of 'off-shore industries, subcontracting chains, and flexible specialization' (Chen, 2012: 5), as well as changing the nature of jobs from standard to nonstandard, and contracting production to small firms and/or informal workers (Portes et al., 1989; Chen, 2012). Hence, driven primarily by the desire to make a profit (Moser, 1978), formal enterprises or capitalists are able to remain competitive by engaging in the informal economy (Castells and Portes, 1989; Becker, 2004; Chen, 2007).

For its part, Legalist/Neo-liberal theory tends to focus primarily on how microenterprises respond to government bureaucracy and regulation. This theory sees firms as making a deliberate choice to carry out their activities in the informal economy as a result of government over-regulation of, or/and interventions in, the market. Whereas the Structuralist theory argues that a government's market intervention and provision of social protection facilitates an efficient and growing economy and 'individual self-realisation', the neoliberals, in contrast, believe the opposite. Particularly, the neoliberals advocate the removal of all forms of restriction to the free market system, because they see 'state interference in the economy and state provision of social protection as interfering with individual freedoms and the ability of the market to optimise the efficient allocation of resources' (Williams 2013: 264). Similarly, Legalist theory argues that the 'hostile legal system [which] leads the selfemployed to operate informally with their own informal extra-legal norms' is principally responsible for informality (Chen, 2012: 8). Specifically, the Legalist theory argues that firms' participation in the informal economy is by choice, so as to avoid the cost, time and rigorous processes associated with the formal registration of their businesses, and the costs of remaining formal: tax burden, salaries and social security contribution burdens, overregulation, and the high cost of public utilities (De Soto, 1989; Becker, 2004; Macias and Cazzavillan, 2009; Dell'Anno and Halicioglu, 2010). The implication of this theory is that a simplification of, and reduction in, the bureaucratic process will enable microenterprises to 
formalise and unleash their productive potential; but if state regulation remains burdensome, microenterprises will continue to operate informally (De Soto 1989; Chen 2012).

Also suggesting participation in the informal economy by choice is the Voluntarist/PostStructuralist theory. Specifically, Voluntarist theory argues that many entrepreneurs consciously choose to carry out their activities in the informal economy, in order to avoid costs such as taxes, rents, and other costs of operating formally (Maloney, 2004; Chen, 2012). Unlike Legalist theory, which emphasises the effect of bureaucracy/over-regulation, Voluntarist theory focuses on the decision making process. Informal participants are considered rational because they engage first in a cost-benefit analysis of the formal economy vis-à-vis the informal economy, before deciding whether or not to operate informally. Similarly, Post-structuralist theory views individuals as making a deliberate choice to operate in the informal economy as a result of 'social, redistributive, resistance or identity reasons' (Adom and Williams, 2013: 5). The theory posits the view that the informal economy exists because participants are 'social' and not 'economic' actors. Economic activities are undertaken in the informal economy for social ties/network reasons (Persson and Malmer, 2006), or to rediscover true self-identity (Snyder, 2004), rejecting the neoliberal system of workers' exploitation and corruption in the formal economy (Biles, 2009; also see Adom and Williams, 2013).

\subsection{Determinants of the informal economy}

The foregoing discussion has revealed different factors which influence decisions to undertake activities in the informal sector or otherwise. Considering the empirical analysis in Section 4, and the need to clarify the way and extent to which these factors influence the informal economy, we consider further these determinants.

We begin with government (over)regulation, which the Legalist/Neo-liberalist theory views as responsible for informality. Regulations such as (excessive) labour market regulation, social security legislation, and other legislation which creates bottlenecks in a firm's recruitment and operational processes, have been found to have a significant influence on decisions to participate in the informal economy (Hart, 2012; Schneider et al., 2010). This can include excessive regulation of the labour market, via minimum wages or maximum working hours. Results from OECD studies show that setting minimum wages increases the level of unemployment and size of the informal economy (Schneider and Enste, 2000). In addition, social security contributions tend to increase the cost of labour in the formal economy, and hence increase the size of the informal economy (Schneider et al., 2010). Particularly, it increases the costs of production, and reduces the profit margin to the employer, if he is unable to shift the burden to the employee. However, if the cost of social security is successfully shifted by the employer, it reduces the actual wages of the employee. The channel of impact is twofold: if the cost of labour becomes too high and profit margins become too low, employers are forced to look for alternative ways of reducing costs, hence, they turn to the informal economy to drive down the cost of production in order to shore up 
their profit. Conversely, if the effect of social security contributions is shifted to employees, they are forced to seek ways of earning extra income, including from the informal economy.

Another determinant of the informal economy is tax burden. Arguably, rising tax burden initiates an expansion in the size of the informal economy, as individuals and/or firms are compelled to seek alternative sources of income from that sector (Giles et al., 2000; Sookram and Watson, 2008). A growing informal economy places further pressure on the government to increase taxes which, in turn, encourages more economic agents to informalise. Additionally, there is an incentive to participate in the informal economy if, in the official economy, the difference between the total cost of labour and after-tax earnings is high, as individuals would seek to avoid the difference and participate in the informal economy (Schneider and Enste, 2000). Contrary to expectations, evidence from Austria suggests that the size of the informal economy did not experience a significant reduction, despite a huge fall in the direct tax burden (Schneider, 1998).

The informal economy is also influenced by under-regulation and/or inadequate commitment from governments, as argued by the structuralist theory. This leaves the informal economy unattended to by the government, and the former's potentials, contributions and problems also become unknown to the latter. As a result, no action is taken to intervene in the sector, since, as argued by Modernism, the informal economy will die out as a passing phenomenon (Becker, 2004). Similarly, many formal institutions have become weak, hence, are not able to 'provide education, training and infrastructure as well as other incentives for structural reforms [, which] has contributed to the growth of the informal economy' (Becker, 2004: 9). In turn, a relatively large informal economy reduces state revenue and its ability to provide a large quantity and quality of public goods (Schneider and Enste, 2000), and sufficient regulations. Any attempt by the government to stem the tide by raising tax rates for individuals/firms operating in the formal economy, only exacerbates the economic situation, as it provides further incentives for these operators to move over to the informal economy.

Again, due to the problems of bureaucracy/over-regulation and corruption as argued, respectively, by the neoliberals and post-structuralists (see also modernism), individuals trying to start-up businesses are neither able to obtain business licence/permits, land titles, nor meet the excessive costs-requirements, in time. This encourages participation in the informal economy. Indeed, "informality was observed to be more pervasive in countries requiring entrepreneurs' compliance with a large number of procedures to start a business and in those in which the time and cost associated with business entry were high" (GarciaBolivia, 2006: 6). Similarly, studies have observed that the size of a country's informal economy increases with corruption, as entrepreneurs deliberately informalise in order to avoid the high costs associated with bureaucracy and corruption (Schneider and Enste, 2000; Ferraira-Tiryaki, 2008). Conversely, other studies (Dobson and Ramlogan-Dobson, 2012) do not consider corruption to be a drawback and, if anything, see it as potentially beneficial to economies with a large informal sector and weak institutions. Further, the informal economy can reduce levels of corruption (Choi and Thum, 2005; Dreher et al., 2005) because asking 
for bribes from entrepreneurs in the formal economy can push them towards the informal economy. To avoid this, corrupt bureaucrats are forced to abide by the rules (Choi and Thum, 2005) of not collecting bribes.

An assertion recently gaining acceptance in the literature is that participants in the informal economy are entrepreneurs, who engage in the sector based either on 'need' or 'opportunity' (Williams and Nadin, 2010), and display such entrepreneurial traits and attributes as: innovativeness, autonomy, ability to identify opportunities, determination, creativity, dynamism and risk-taking (Bouchard and Dion, 2009; Williams and Nadin, 2010). Also, some economic units engage in the informal economy because of their desire and decisions to become self-employed and avoid the high cost of labour, burden of taxation, corruption and bureaucratic costs (Neuwirth, 2011) and burden of state overregulation (De Soto, 1989). These neoliberal, post-structuralist, views contrast with the structuralist, modernisation view, as the latter suggests that people engage in the informal economy to survive. Specifically, neoliberals argue that informal entrepreneurship is based on 'choice' whilst in contrast, structuralists view informal entrepreneurs as being motivated by 'necessity', adopting a last-resort strategy (Williams, 2013; Castells, and Portes, 1989; Gallin, 2001). Thus, structuralists describe informal entrepreneurship as involuntary, forced, reluctant, or survivalist (Singh and De Noble, 2003; Travers, 2002; Williams and Nadin, 2010).

Another factor that influences the informal economy is time allocation, which determines different occupations (Sookram and Watson, 2008). Arguably, time is a scarce commodity and has to be distributed optimally between work and leisure on the one hand, and between the informal sector and household-related work on the other. Similarly, there are multiple activities that can be carried out by individuals/firms, but the latter would have to do so within the space of time available to all economic agents. For example, individuals who have formal employment can choose to combine it with activities in the informal economy, but they can only do so if they have spare time from their formal job, and/or are willing to trade off their leisure time for these informal activities. Schneider and Enste (2003) suggest a seamless movement of individuals between the two sectors, but other empirical results tend not to support this hypothesis. For example, Lemieux et al. (1994) report a negative relationship between the formal economy and time spent in the informal economy, and Sookram and Watson (2008) found marginal evidence in favour of time spent in the formal and the informal economy for Trinidad and Tobago.

In addition, socioeconomic factors such as level of education (Gallaway, and Bernasek, 2002), area of residence (Sassen-Koob, 1989), income level, number of dependents (Schneider et al., 2001), skills acquired, and training undergone (Becker, 2004), and demographic factors, such as marital status (Schneider et al., 2001), age and sex (Becker, 2004; Loayza, 1996) tend to affect the size of the informal economy. For example, sectors dominated by ease of employment, particularly employment without documentation, lowwage, low income, low-skills, and labour-intensive jobs, which can be categorised as structuralist factors (see Williams, 2013), have a relatively larger share in the informal 
economy (Sookram and Watson, 2008). Also found is the prevalence of the informal economy in manufacturing (Castells and Portes, 1989; ILO, 2002) and construction (Marceli et al., 1999; Losby and Edgcomb, 2002). Again, Becker (2004) notes that the growing number of women going into the labour market contributes to the growth of the informal economy, as they do not have the right to own property/land in some countries, hence cannot operate formally.

To conclude this section, it is important to reiterate that while most of these factors, for convenience, can be summarised under the headings structuralist (i.e., survivalist and underregulation determinants), neoliberal (i.e., choice, over-regulation, bureaucracy), and poststructuralist (i.e., choice, corruption, social, redistributive, resistance or identity reasons), some overlaps exist. In the next section, we discuss methods employed in establishing which of these factors determine the Nigerian informal economy.

\subsection{Methods}

This paper employs direct methods to investigate the determinants of the Nigerian informal economy. Direct methods involve the use of designed instruments, interviews and observations to obtain information about the participants and activities undertaken in the informal economy (Williams, 2006; Sookram and Watson, 2008; Devey et al., 2006). It contrasts with indirect methods, which is based on the discrepancy between national income and expenditure, discrepancy between the official and actual labour force, transactions carried out in the economy, the amount of currency demanded in the economy, or electricity consumption (Schneider and Enste, 2000). Although, direct methods can be critiqued for producing only point estimates of the informal economy (Schneider, 2002), they suit well the focus of this study.

Again, direct survey methods can be influenced by the way survey instruments are designed, and could suffer from imprecision and unhelpful responses from unwilling and uncooperative respondents, which could negatively impacts findings. Similarly, the difficulties associated with accessing informal activities through questionnaires, the possible unreliability of responses if participants are concerned about confessing to fraudulent activities and behaviour, and the difficulty associated with determining the actual monetary value of activities carried out in the informal economy, are also criticisms of the survey method found in the literature. These challenges were effectively mitigated in this paper by the way the survey instrument was designed (see Section 3.1). It is also worth reiterating that only the direct method can generate relevant information when the focus of a study, as here, is on obtaining detailed information about the characteristics of the individuals, households and firms operating in the informal economy.

For data analysis, this paper employs the multiple cause, multiple indicator (MIMIC) method, a model-based method which involves the use of models to investigate the possible causes and effects of the informal economy (Section 3.2). 


\subsection{Data sampling \& questionnaire design}

To collect the data in our analysis, we combined two methods that have been employed in the informal economy literature: a "street-by-street survey" (Reddy et al., 2003:137), and the spatial random sampling method (Williams, C. and Round, 2009). While the former involves administering a survey instrument to members of the public, the latter involves selecting every alternate location and participant for sampling. Thus, we went to public motor parks/garages, open-street markets, business premises, vendors on the street, and kiosks/workshops to select every alternate adult/owner of a business outfit that was willing to complete our questionnaire, and in instances where an individual declined, the next person was sampled and the one after was skipped. The data gathering exercise took place between May 2012 and March 2013 across 5, out of the 6, regions (covering 23 of the 36 states) in Nigeria. Overall, we administered about 1200 questionnaires, and achieved a success of 647 responses.

In order to ensure that the questionnaire was able to solicit information capable of fulfilling the goal of this study, and be consistent with the existing literature, we designed questions that could reveal information about the main determinants of the Nigerian informal economy, then we referred to previous studies to refine the questionnaire (Hussmanns, 2004; Myanmar, 2009; Maligalig and Guerrero, 2008; ADB, 2011; Becker, 2004). To capture all aspects of the informal economy in Nigeria, as well as generate statistics that are internationally comparable (Maligalig and Guerrero, 2008), sufficient questions were built into the survey instrument. For example, the important variables that represent different definitions and survey approaches of the informal economy are provided by Becker (2004) Hussmanns (2004) and Myanmar (2009). Our survey instrument was designed to ask questions about these variables. The strength of our method is that it covers all aspects of the informal economy (as severally defined) in Nigeria, considering that a single Nigerian government definition of the informal economy, to the best of our knowledge, does not exist. Finally, to mitigate problems associated with surveying the informal sector, our questionnaire was designed to ask several questions in different ways, which serve as checks on each other.

\subsection{Model Specification: Multiple-Cause, Multiple-Indicators (MIMIC) model}

The MIMIC model, "a particular type of a structural equations model (SEM)" (Schneider et al., 2010:10), is based on the statistical theory of latent variables, which considers multiple causes and indicators of the informal economy (Dell'Anno, 2007). It is arguably the most robust technique theoretically. The method defines and depicts the association between the observed causes and effects of the informal economy, which is the unobserved variable, to compute the unobservable factors of the informal economy. The MIMIC model is a combination of two models: the measurement or confirmatory factor analyses (CFA) model and the structural model (SM), which are specified concurrently. The process begins with the CFA model, which defines the links between the unobserved variable and the observedindicator variables. It can also be specified to define the links between the latent variable and 
the observed-causal variables (Byrne, 2010). Following the specification of the CFA model is the SM, which defines the relationship between the unobserved variables. Effectively, the SM represents the bridge between the latent variable and its causal factors, and the latent variable and its indicator-factors. MIMIC models mainly confirm structural theories. They are designed and used as confirmatory techniques, as they primarily test, with actual data, the representativeness and consistency of the structural model. In doing this, they fulfil two objectives; estimate parameters, and gauge the fit of the model (Schneider et al., 2010). Thus, the SM part of the MIMIC model for this paper is specified as:

$\mathrm{M}=\mathrm{Df}+E$

Where $f=\left(f_{1}, \ldots, f_{k}\right)=(1 x k)$ vector, and potentially, each $f_{i}, i=1, \ldots, k$ can cause the latent variable $M$. The vector of coefficients is represented by $D=\left(d_{1}, d_{2}, \ldots, d_{k}\right)$ is a $(1 \times k)$ and it describes the relationship between the latent (unobserved) variable and its causes. This implies that a combination of exogenous causes determine the latent variable $M$. It is assumed that the explanatory factors specified in the model may not explain all the variations in the latent variable, M. Hence, an error term $E$ is added to the equation in order to account for the unexplained part. $\mathrm{H}$ represents the variance of $E$, and $\mathrm{L}$ defines the (k x k) covariance matrix of the factors which determine $f$.

The connection between the unexplained factors and their indicators is defined by the measurement model, specified as:

$\mathrm{D}=\mathrm{gM}+U$

Where $\mathrm{D}=\left(\mathrm{d}_{1}, \mathrm{~d}_{2}, \ldots, \mathrm{d}_{\mathrm{t}}\right)=(1 \mathrm{xt})$ vector of the multi-indicator variables, $\mathrm{g}$ represents the vector of the regression coefficients, $U$ represents the $(1 \mathrm{xt})$ vector of the white noise disturbances, and $\mathrm{Q}_{U}$ is the (txt) covariance matrix.

Combining Equations (1) and (2) will generate Equation (3), which is a "reduced form [of] multivariate regression model" (Schneider et al., 2010: 12). Equation (3) is defined by $\mathrm{d}_{\mathrm{n}}$, $\mathrm{n}=1, \ldots, \mathrm{t}$ (endogenous variables), which are the indicators of the M's unexplained variables, and $f_{i}, i=1, \ldots, k$ (exogenous variables), which are the causes of the M's latent variable:

$\mathrm{d}=\mathrm{Pf}+V$

Where $\mathrm{P}=\mathrm{gD}$, a unit-ranked matrix, and $V=\mathrm{g} E+U . V$, the error term, is a (tx1) vector which combines the white noise error terms of the structural model $(E)$ and measurement model $(U)$. $V \sim(0, \mathrm{~N})$. N's covariance matrix is unit-ranked, and is defined as: $\operatorname{cov}(V)=\mathrm{Z}(\mathrm{g} E+U)(\mathrm{g} E+U)$ ' $=\mathrm{gg}$ ' $\mathrm{H}+\mathrm{L} v$. For the model to be identified and estimated, one of the components of vector $\mathrm{g}$ must be normalised to an exterior or fixed value (Bollen, 1989; Schneider et al., 2010). Also, the covariance matrix of the MIMIC model $\sum(\mathrm{L})$ defines the co-varying relationships between the observed variables, and is derivable from Equations (1) and (2). Finally, the latent and observed variables' structure of the MIMIC model emerges when the resulting matrix from Equation (1) and (2) is decomposed. Thus: 


$$
\Sigma(L) \quad=\quad\left(\begin{array}{cc}
g(D q Y+h)+L_{U} & g D q \\
q Y g & q
\end{array}\right)
$$

Where $\sum(\mathrm{L})$, the covariance matrix, depends on the parameters of $\mathrm{g}$ and $\mathrm{Y}$, as well as the covariances contained in $\mathrm{q}, \mathrm{L}_{U}$, and $\mathrm{H}$. Generally, the estimation of the hypothesised model would yield exact results as that of the population's covariance matrix $\left(\sum\right)$, that is, $\sum=\sum(\mathrm{L})$, if the former model's parameters are known, and correct. However, this is not the case in practice as the parameters, variances and covariances of the population are never known; only those of the samples are known. Hence, what is available for use for the estimation of the model, are the observed variables' sample covariance matrix, which are the $\mathrm{d}$ (vector of indicators) and $\mathrm{f}$ (vector of causes), and the estimates of the unknown sample parameters. Overall one aims, as much as possible, to produce the closest possible parameter and covariance estimates to the sample covariance matrix, that is, $\sum^{*}=\sum\left(\mathrm{L}^{*}\right)$, of the observed causes and indicators. "The function that measures how close a given [population covariance matrix] $\sum^{*}$ is to the sample covariance matrix $\mathrm{S}$ is called fitting function $\mathrm{F}\left(\mathrm{S} ; \sum^{*}\right.$ )" (Schneider et al., 2010: 13). For most SEM users, the Maximum Likelihood (ML) estimation technique is the most popular fitting function, and is given as:

$\mathrm{F}_{\mathrm{ML}}=\log \left|\sum(\mathrm{L})\right|+\mathrm{ni}\left[\mathrm{S} \sum^{-1}(\mathrm{~L})\right]-\log |\mathrm{S}|-(\mathrm{t}+\mathrm{k})$

Where $\log \mid$ | represents the log of each matrix's determinants, and the number of observable variables is $(\mathrm{t}+\mathrm{k})$. The application of the dynamics of Equations (1) to (5) leads to the computation of the coefficients of the explanatory variables, loosely termed MIMIC results, which are depicted in Table 2.

\subsection{Results presentation}

\subsection{Descriptive statistics}

Table 1 depicts the information about respondents' marital status, sex, and age statistics. It is clear from the table that over two-thirds of participants are male (68.7\%) and married (74.2\%). With an estimated 51\% male and 62.7\% married Nigerian population (NPC, 2006), participants' marital status depicts a closer proximity to the true population than participants' sex. These statistics suggest a high participation rate for male and married Nigerians in the informal economy. Table 1 also shows that respondents' mean and standard deviation ages are 40 and 11 years respectively. The low standard deviation from the mean age is indicative of an evenly distributed sample.

Table 1: Respondents' marital status, sex, and age statistics

\begin{tabular}{llllll}
\hline Marital status & $\%$ & Sex & $\%$ & Age Statistics & \\
\hline Married & 74.2 & Male & 68.7 & Mean & 40 \\
\hline Separated/divorced & .2 & Female & 31.3 & Median & 40 \\
\hline Widowed & 2.1 & & & Std. Deviation & 11 \\
\hline Not married & 23.4 & & & & \\
\hline
\end{tabular}


Table 2 shows the reasons for engaging in a job or business activity in the informal economy. It is clear from the table that, while respondents engage in the informal economy for many reasons, the need to survive and high levels of unemployment appear to be the dominant reasons for doing so in Nigeria. However, operating in the Nigerian informal economy equally has its challenges, as participants are confronted with inadequate finance, high interests, and inaccessible loans (Table A2).

Table 2: Rankings of the reasons for operating in the informal sector $(\%)$

\begin{tabular}{lllllllllll}
\hline & $1^{\text {st }}$ & $2^{\text {nd }}$ & $3^{\text {rd }}$ & $4^{\text {th }}$ & $5^{\text {th }}$ & $6^{\text {th }}$ & $7^{\text {th }}$ & $8^{\text {th }}$ & $9^{\text {th }}$ & No.1 \\
\hline Unemployment/No other job & 53.9 & 15.6 & 7.1 & 5.0 & 2.1 & 3.5 & 2.8 & 2.1 & 7.8 & 24.7 \\
\hline $\begin{array}{l}\text { Autonomy/Want own } \\
\text { business }\end{array}$ & 27.9 & 13.6 & 17.7 & 11.6 & 8.2 & 7.5 & 4.8 & 5.4 & 3.4 & 13.9 \\
\hline Difficult to register business & 5.5 & 8.3 & 3.7 & 4.6 & 7.3 & 21.1 & 19.3 & 15.6 & 14.7 & 2.7 \\
\hline Tax avoidance/Less tax & 4.7 & 5.7 & 8.5 & 10.4 & 6.6 & 11.3 & 14.2 & 17.9 & 20.8 & 1.7 \\
\hline Survival & 59.1 & 20.2 & 7.7 & 2.9 & 2.9 & 2.9 & 2.4 & 1.9 & & 42.4 \\
\hline Not costly to start/operate & 9.2 & 13.4 & 16.0 & 12.6 & 18.5 & 10.9 & 8.4 & 8.4 & 2.5 & 3.7 \\
\hline Less regulations & 4.8 & 6.7 & 5.8 & 9.6 & 21.2 & 18.3 & 14.4 & 11.5 & 7.7 & 1.7 \\
\hline Easy entrance & 13.3 & 12.5 & 23.4 & 19.5 & 10.9 & 4.7 & 4.7 & 4.7 & 6.3 & 5.8 \\
\hline More profitable & 7.8 & 6.9 & 7.8 & 15.5 & 11.2 & 5.2 & 12.1 & 16.4 & 17.2 & 3.4 \\
\hline Total & 100 & 100 & 100 & 100 & 100 & 100 & 100 & 100 & 100 & 100 \\
\hline
\end{tabular}

Finally, a preliminary analysis of respondents' demographic and socio-economic factors shows that religion, age, marital status and level of education influence the size of the Nigerian informal economy (Tables 3 and 4). Specifically, the results suggest that more Muslims than Christians, more married than not-married, and more older than younger, Nigerians engage in the informal economy. The results also suggest that people with lower educational qualifications are more likely to participate in the informal economy than their counterparts with higher qualifications. 
Table 3: Participants' main job or business VS. sex, religion \& marital status.

\begin{tabular}{|c|c|c|c|c|c|c|c|c|c|c|c|c|c|}
\hline & & \multicolumn{4}{|l|}{ Sex } & \multicolumn{4}{|l|}{ Religion } & \multicolumn{4}{|c|}{ Marital status } \\
\hline & & Male & Female & Total & Freq. & Christian & Muslim & total & Freq. & married & Not marr. & total & Freq. \\
\hline \multirow[t]{2}{*}{ Self-employed } & \%within MAINJ & 69.1 & 30.9 & 100 & \multirow[t]{2}{*}{191} & 79.6 & 20.4 & 100 & \multirow[t]{2}{*}{191} & 78 & 22 & 100 & \multirow[t]{2}{*}{191} \\
\hline & \%within variable & 47 & 46.5 & & & 43.2 & 69.6 & & & 48.7 & 41.2 & & \\
\hline \multirow[t]{2}{*}{ Govt. employee } & \%within MAINJ & 67.3 & 32.7 & 100 & \multirow[t]{2}{*}{165} & 92.7 & 7.3 & 100 & \multirow[t]{2}{*}{165} & 81.8 & 18.2 & 100 & \multirow[t]{2}{*}{165} \\
\hline & \%within variable & 39.5 & 42.5 & & & 43.5 & 21.4 & & & 44.1 & 29.4 & & \\
\hline \multirow{2}{*}{$\begin{array}{l}\text { Corporate employee/ } \\
\text { students/applicant }\end{array}$} & \%within MAINJ & 73.1 & 26.9 & 100 & \multirow[t]{2}{*}{52} & 90.4 & 9.6 & 100 & \multirow[t]{2}{*}{52} & 42.3 & 57.7 & 100 & \multirow[t]{2}{*}{52} \\
\hline & $\%$ within variable & 13.5 & 11 & & & 13.4 & 8.9 & & & 7.2 & 29.4 & & \\
\hline Total & & 68.9 & 31.1 & 100 & & 86.3 & 13.7 & 100 & & 75 & 25 & 100 & \\
\hline Total responses & & & & & 408 & & & & 408 & & & & 408 \\
\hline Chi square & Phil (nom dich) & \multicolumn{3}{|c|}{$.039(.73)-$ Not sig } & & $.184 * * *$ & & & & \multicolumn{3}{|l|}{$.291 * * *$} & \\
\hline Pearson & & \multicolumn{3}{|c|}{$-.013(.79)-$ Not sig } & & $-.167 * * *$ & & & & \multicolumn{3}{|l|}{$.186 * * *$} & \\
\hline Kendal's tau-c & & \multicolumn{3}{|c|}{$-.008(.876)-$ Not sig } & & $-.121 * * *$ & & & & \multicolumn{3}{|l|}{$.138 * * *$} & \\
\hline
\end{tabular}

:

Table 4: Participants' main job/business activity VS. level of education \& age group.

\begin{tabular}{|c|c|c|c|c|c|c|c|c|c|c|c|}
\hline & & \multicolumn{4}{|c|}{ Level of education } & \multicolumn{6}{|c|}{ Age group of participants (years) } \\
\hline & & $\geq$ bachelor & $\geq \mathrm{HI}<$ bachelor & $\leq$ secondary & Total & $17-25$ & $26-30$ & $31-40$ & $41-50$ & $>50$ & total \\
\hline \multirow[t]{2}{*}{ Self-employed } & \%within MAINJ & 31.9 & 26.2 & 41.9 & 100 & 7 & 16.2 & 27 & 25.9 & 23.8 & 100 \\
\hline & \%within variable & 30.0 & 50.5 & 75.5 & & 46.4 & 46.9 & 42.7 & 52.7 & 51.8 & \\
\hline \multirow{2}{*}{ Govt. employee } & \%within MAINJ & 69.7 & 25.5 & 4.8 & 100 & 2.6 & 15.6 & 35.1 & 27.3 & 19.5 & 100 \\
\hline & $\%$ within variable & 56.7 & 42.4 & 7.5 & & 14.3 & 37.5 & 46.2 & 46.2 & 35.3 & \\
\hline \multirow{2}{*}{$\begin{array}{l}\text { Corporate employee/ } \\
\text { students/applicant }\end{array}$} & \%within MAINJ & 51.9 & 13.5 & 34.6 & 100 & 23.9 & 21.7 & 28.3 & 2.2 & 23.9 & 100 \\
\hline & $\%$ within variable & 13.3 & 7.1 & 17 & & 39.3 & 15.6 & 11.1 & 1.1 & 12.9 & \\
\hline Total & & 49.8 & 24.3 & 26 & 100 & 7.3 & 16.6 & 30.4 & 23.6 & 22.1 & 100 \\
\hline Total responses & & & & & 408 & & & & & & 385 \\
\hline Chi square & Cramer's V & $.307 * * *$ & \multicolumn{9}{|c|}{$.216 * * *$} \\
\hline Pearson & & $-.258 * * *$ & \multicolumn{9}{|c|}{$-.12 * *$} \\
\hline Kendal's tau-c & & $-.257 * * *$ & \multicolumn{9}{|c|}{$-.089(.07)$} \\
\hline Spearman & & \multicolumn{10}{|l|}{$-.303 * * *$} \\
\hline
\end{tabular}

Where: MAINJ $=$ main job or business, $* * * \& * *=$ significant at $1 \% \& 5 \%$ respectively, ()$=$ p-values, HI=higher institution 


\subsection{MIMIC analysis}

Employing Equations 1-5, relevant variables in Sections 4.1, 4.2.1, and existing theories of the informal economy, we build a model of the determinants of the Nigerian informal economy. As explained in Section 3.2, the first task in a MIMIC/SEM analysis is to achieve a best-fit model, built on the basis of existing theories. Thereafter, any variable in the chosen (best-fit) model which meets the MIMIC diagnostic criteria is considered important. It will then be included in the final model as an important determinant of the informal economy in Nigeria. These diagnostic criteria, which are further discussed in Section 4.2.2 are: Normed Fit Index (NFI), Comparative Fit Index (CFI), and the Root Mean Square Error of Approximation (RMSEA).

\subsubsection{Important Variables: causal and indicator factors.}

\subsubsection{Causal factors:}

Regulatory burden (REGB): The literature on the informal economy is very clear on the major role played by government regulatory burden in encouraging informal economic activities (Section 2). Additionally, participants in our survey think regulation influences the size of the Nigerian informal economy (Table A1). The proxy for regulatory burden is participants' responses to the statement, 'government regulation of the informal economy is too much'. It is a five-scale response question, and a positive sign is expected.

Unemployment (UNEMP): Unemployment was a key causal factor of the informal economy in early debates. Evidence from our data (Table 2) suggests the factor still influences the size of the informal economy. Table 2 shows that unemployment and survival are the main reasons for taking up a job/business activity in the informal economy in Nigeria. The proxy for unemployment is the participants' ranking of the reasons for engaging in the informal economy, which has been recoded into scale-data ranging from 1 to 10 , where each of 10, 9 $\ldots 2$ takes the place of $1^{\text {st }}, 2^{\text {nd }} \ldots 9^{\text {th }}$ ranks respectively. Generally, scale data are more suitable for the type of analysis carried out in this section, especially as data for the other factors in the section are scale data. A positive relationship between the Nigerian informal economy and unemployment is hypothesised.

Autonomy/self-employment (AUTO): Analysis of individuals' desire to own their businesses or have working-flexibility and autonomy has recently emerged in the literature, as a factor which has led many to undertake business activities in the informal economy. Our data tends to support this. Suggestively, not all participants engage in the informal economy because there are no alternatives (Tables 2; A1); rather, some participate in the sector by choice. The data used as a proxy for autonomy were constructed in a similar way to that described for unemployment above. A positive relationship between the informal economy and autonomy is hypothesised. 
Corruption or Business freedom $(B F)$ : Business freedom measures the kind of environment participants operate in. Responses to the statement, 'it is very difficult to operate in the informal economy without giving bribes to some law enforcement agencies' were used as a proxy for BF (Table A1). Thus, BF measures the level of corruption in the Nigerian informal economy. Corruption is a key determinant of the informal economy, as shown in Section 2. $\mathrm{BF}$ is derived from scale data with five points, ranging from strongly agreed to strongly disagreed; a positive relationship is expected between this factor and the informal economy.

Tax burden (LTAX): One factor which has been investigated extensively in the informal economy literature, as a key determinant of the informal economy, is tax burden. Used in this section as a proxy for tax burden is 'less tax', which is one of the ranked reasons for engaging in informal activity (Table 2). Data computation is similar to the process for computing unemployment, described above. A positive relationship is hypothesised between LTAX and the informal economy.

Survival (SURV2): The need to survive is another factor that is arguably responsible for a large informal economy (Section 2). The data in Table 2 tend to support this. In particular, most participants ranked survival as the main reason for engaging in the informal economy. Survival is represented by participants' responses to the statement, 'if government can provide jobs for all Nigerians, nobody will operate in the informal economy'. The data are constructed following the process for computing BF. A positive relationship is hypothesised between survival and the informal economy.

\subsubsection{Indicators}

The activities of the informal economy may not be captured officially, but they manifest in a number of ways. To unravel the relevant indicators for the Nigerian informal economy, participants were asked to rate the following statements from strongly agreed to strongly disagreed, which were later computed into scale data:

Government should discourage the informal economy as it is harmful to the Nigerian economy (HPF): Respondents overwhelmingly refuted this statement (Table A1, Column D). Suggestively, an opposing statement is possibly true. This assumption is based on the consistency of participants' responses to questions on such variables as wealth (WTH), growth (GROT) and overcome poverty (OPOV). Thus, it can be inferred from these responses that the informal economy in Nigeria is economically useful (HPF) to its participants and the Nigerian economy, hence, should not be discouraged. Accordingly, HPF was constructed as an indicator factor to enable us to carry out a MIMIC analysis.

Informal sector activities are good for Nigeria's economy (GROT): This statement is straightforward and gained overwhelming acceptance from participants (Table A1, Column E). We have constructed the GROT indicator to represent these positive economic (e.g., economic growth and income generation) effects of the Nigerian informal economy. 
People are poor because they work or do business in the informal economy as they are disadvantaged (WTH): Similar to the responses on the HPF indicator, respondents also disagreed with this statement (Table A1, Column F). A contrasting statement is arguably correct; particularly, people are able to build up wealth (WTH) by working or doing business in the Nigerian informal economy. Thus, we construct WTH as a wealth indicator for the informal economy.

Government does not have sufficient revenue as participants in the informal sector do not pay tax' (TAXR): Respondents tend to disagree with this statement (Table A1, Column G). Suggestively, the opposite of this statement is possibly true. Again, as argued under HPF, our assumption is based on the consistency of participants' responses to other questions that are related to TAXR. Hence, TAXR is constructed as an indicator of an informal economy which generates tax revenue through levies, taxes and ticket fees to the Nigerian government.

Proportion of income from main job (PYMJ): The PYMJ was constructed from participants' responses to the question, what proportion of your income is earned from main job?

\subsubsection{MIMIC results.}

Table 5: MIMIC results

\begin{tabular}{ll}
\hline Path & Model D \\
\hline UNEMP $\rightarrow$ INFEC & $.077^{* *}$ \\
\hline AUTO $\rightarrow$ INFEC & $-.109^{* *}$ \\
\hline BF $\rightarrow$ INFEC & $.181^{* *}$ \\
\hline LTAX $\rightarrow$ INFEC & $.080^{* *}$ \\
\hline SURV2 $\rightarrow$ INFEC & $.196^{* *}$ \\
\hline INFEC $\rightarrow$ HPF & 1 \\
\hline INFEC $\rightarrow$ WTH & $.500^{* *}$ \\
\hline INFEC $\rightarrow$ GROT & $.627^{* *}$ \\
\hline INFEC $\rightarrow$ TAXR & $.496^{* *}$ \\
\hline INFEC $\rightarrow$ PYMJ & $-.051\{.052\}$ \\
\hline CMIN $\{$ P-V\}; NFI; IFI; CFI & $41.9\{.137\} ; .8 ; .95 ; .94$ \\
\hline RMSEA (L-H); AIC (D; S; I) & $.025(.00-.046) ; 106 ; 130 ; 227$ \\
\hline Total responses & 418 \\
\hline Note: $\{$ $=$ p-value; $* *=$ sig at 5\%; INFEC=informal economy; -v=p-values; L-H=lowest-highest; CMIN (Chi- &
\end{tabular}

Table 5 depicts the results of the MIMIC model. The important diagnostic statistics for this model, the IFI, CFI, and RMSEA, are good statistically, but the NFI is not very good. However, considering the influence of sample size on NFI, the CFI has been recommended as the index of choice (Bentler, 1992). Generally, a CFI value greater than 0.9 (Bentler, 1992) or a value close to 0.95 (Hu and Bentler, 1999) are "considered representative of a well-fitting model" (Byrne, 2010: 78). The same is true for the IFI. Thus, our model meets all relevant diagnostic criteria sufficiently.

Additionally, the badness-of-fit measure is statistically significant for our model. Particularly, with a value of 0.025 , the RMSEA shows that the MIMIC model is well-fitting. Finally, the 
AIC criterion is met, as all values of the dependent model, in all cases, are lower than both the saturated and independent models. Accordingly, we accept that the values of these indices are good and statistically significant, to allow us to use this model for our analysis.

\subsection{Discussion}

As can be seen from Table 5, the factors responsible for the origin and expansion of the Nigerian informal economy are: UNEMP (unemployment: no other jobs), AUTO (autonomy: need to be autonomous/self-employed), BF (corruption, particularly, of government officials and agencies), LTAX (participants' desire to pay less tax), and SURV2 (survival: participants' need to survive). However, such factors as more profit, government regulation, and difficulty in registering formal businesses (which were initially built into the model were deleted, as they did not pass the best-fit measure) are statistically non-significant, hence not strong determinants of the Nigerian informal economy.

All factors except autonomy (see next paragraph for explanation), have the expected positive sign. This means that an increase in the size of any of the factors, except autonomy, will lead to an increase in the size of the informal economy in Nigeria. Specifically, a unit rise in unemployment, corruption, tax avoidance, and survival triggers a respective $0.077,0.181$, 0.080, and 0.196 points expansion in the size of the Nigerian informal economy. The biggest influence, as one would expect, comes from the survival factor. This implies that many people, who do not have other options, go into the informal economy in Nigeria to engage in activities which enable them to earn a living. In terms of magnitude and influence, survival is closely followed by corruption. The implication of this is that corrupt government officials create an environment which encourages the informal economy in Nigeria.

The contrasting negative sign of the autonomy factor is a bit worrying as it suggests that an increase in the need to be autonomous or self-employed leads to a decline in the size of the informal economy. Clearly, this contrasts with the existing theory on the informal economy which hypothesises a positive relationship between the informal economy and autonomy. However, one possible explanation for this result is that, relatively, the participants' ranking of the autonomy variable is more evenly shared among the ' 9 ranks' than the survival or unemployment variables. For example, the proportion of the first rank (as a percentage of the total ranks for each variable) of each of the unemployment, autonomy and survival variables is respectively $53.9 \%, 27.9 \%$ and $59.1 \%$ (see Table 2). It is thus clear that in the first rank alone, survival and unemployment have more than $50 \%$, but autonomy is just a quarter. Additionally, while survival and unemployment respectively have their rankings in a descending order, it is not so with autonomy which, for its part, shows an irregular pattern in its ranking.

Also from results, it can be seen that the activities of the informal economy in Nigeria are indicated by the following factors: HPF (economically useful to participants and economy), WTH (wealth for participants), and GROT (the informal economy is good for the economy). These indicators experience an increase whenever there is an expansion in the size of the 
Nigerian informal economy. Specifically, a unit increase in the size of the Nigerian informal economy leads to a respective 1.0, 0.5 and 0.63 points increase in HPF, WTH and GROT. The implication of this is that the informal economy contributes positively to the Nigerian economy in total, by creating wealth for participants and contributing to GDP growth.

\subsubsection{Policy implications}

Job provision and entrepreneurial development: Considering that unemployment and survival are often quoted as key reasons for engaging in the informal economy, implementing policies that facilitate the provision of employment will reduce the size of the informal economy in Nigeria. To begin with, such policies should target transitory participants, i.e. job applicants and most university graduates, who operate in the informal economy while engaging in active search for full-time employment. The Nigerian government can facilitate jobs by creating an environment conducive for the private sector to create quality jobs. Although successive Nigerian governments since the SAP era of the 1980s have encouraged private sector-led job-creation, the former has not created a sufficiently enabling environment for the latter to be successful. For example, reported in Table A2 as inhibitors of business operations in Nigeria are: inadequate infrastructures, insecurity, inadequate roads and electricity, and policy inconsistencies. The government of Nigeria should seek, and be committed to, addressing these problems in order for the private sector to thrive and create jobs.

However, it is shown in Section 4.2 that some people participate in the informal economy by choice, and not because there are no jobs. Also, Table 2 shows that some of these participants are with low educational qualifications, secondary school drop outs, and those without a formal education. Clearly, these categories of participants will require a system which enables them to develop job-related and entrepreneurial skills in order to achieve gainful employment. Policies which encourage the setting up of apprenticeship systems and reforms in the education system would be of great help. Those with skills gaps can be trained, and those without a formal education can then be helped to go through the apprenticeship system.

Deal with Corruption: Some participants in the informal economy find it difficult to register their enterprises, because of the bureaucratic nature of the process of registration and government institutions, whilst some participants are mishandled and harassed by corrupt government officials (Tables 2; A2). Arguably, these government officials will prefer an imperfect system and a large number of unregistered informal participants in order for them to continue to collect bribes and levies that are not officially accounted for. To influence the informal economy, the government should address these problems. Particularly, the Nigerian government should be committed to fighting corruption, scaling down the negative effects of bureaucracy and reversing the execution of projects that benefit only a few Nigerians.

Financial assistance and training for budding entrepreneurs in the informal economy: While funding is germane to the success of an enterprise, inadequate access to finance/credit facilities can be a constraint, and highlighted as one of the main problems facing participants 
in the Nigerian informal economy (Table A2). The government can support these businesses by facilitating accessibility to finance directly and/or indirectly. Direct support can be in the form of budgetary allocations to the sector, disbursed through a specialised financial institution at low interest rates. Indirect support can be in the form of a guarantee for any commercial bank's scheme (e.g. a designed product which reduces the credit criteria and complexities for targeted clientele), which makes credit easily accessible to informal enterprises. With these schemes in place, qualifying informal enterprises will not be denied access to finance because of their limited initial capital outlay. Also, it will provide access for the participants who need funds for expansion, but who consider the commercial banks' lending rates too high. Finally, by providing financial support through these schemes, the government can initiate a system which facilitates the formalisation of these informal enterprises and participants.

Related to finance, is the need to facilitate training for the budding entrepreneurs in the informal economy, as some of these participants who seek relevant technical, financial and managerial skills to improve their business performance often do not know how and where to go for such training. Government can step in to close this gap. To begin, the education system should be reformed to suit what the nation needs for development. For example, training in entrepreneurship should be added to the curriculum of schools and higher institutions to enable those who have the innate skills to add on formal training. Additionally, the government of Nigeria can provide a special school for the formal training of informal participants, which is akin to what it did recently for nomadic cattle farmers in the Northern region of Nigeria, when it started to provide special schools, at their various settlements. In addition, policies which make primary and secondary school education compulsory for all citizens should be enforced. Finally, if an apprenticeship system is developed, as recommended in the previous section, participants in the informal economy who do not want to attend university, will be able to receive the training that will enable them to fully hone their entrepreneurial skills.

\section{Conclusions:}

Employing primary data and the MIMIC approach, this study reports five factors which determine the size of the Nigerian informal economy: survival, unemployment, corruption, autonomy, and less tax. Following these findings, appropriate policy recommendations were proposed. These findings and recommendations could be applicable to other countries with similar sizes and structure of informal economy since most of the factors reported have been found to be responsible for the origin and expansion of the informal economy in the literature, as discussed in Section 2. However, potential variances in magnitudes and influences could exist for these determinants for each country. This necessitates separate studies for individual countries.

Considering that no single study can cover all aspects of the informal economy, future studies could employ other methods and data to investigate the determinants of the Nigerian informal 
economy. There is a need to have a closer look at data from particular states, and/or employ secondary data in a similar study. The former will enable the researcher to first carry out a household survey to identify those engaged in the informal economy, before sampling these identified groups. This, we could not achieve in the current study due to time, cost and security constraints, considering that our survey covered 23, out of the 36 , states in Nigeria.

\section{References}

ADB, 2011. The Informal Sector and Informal Employment in Indonesia: Country Report 2010. African Development Bank, BPS-Statistics Indonesia, Printed in the Phillipines.

Adom, K. and Williams, C. 2013. Evaluating the explanations for the informal economy in third world cities: some evidence from Koforidua in the eastern region of Ghana. International Entrepreneurship and Management Journal, 10, (2), 427-445.

Becker, K., 2004. The Informal Economy. SIDA Fact Finding Study, SIDA3630en, available online at: www.sida.se/publications, (accessed on 16/10/2011).

Bentler, P. 1992. On the fit of models to covariances and methodology to the bulletin. Psychological Bulletin, 112 (3), 400-404.

Biles, J. 2009. Informal work in Latin America: Competing perspective and recent debates. Geography Compass, 3 (1), 214-236.

Boeke, J. 1953. Economics and economic policy of dual societies, as exemplified by Indonesia. Haarlem, H.D. Tjeenk Willink.

Bollen, K. 1989. Structural Equations with Latent Variables. New York: Wiley.

Bouchard, M. and Dion, C. 2009. Growers and facilitators: probing the role of entrepreneurs in the development of the cannabis cultivation industry. Journal of Small Businesses and Entrepreneurship, 22 (1), 40-57.

Bureau, S. and Fendt, J. 2011. Entrepreneurship in the informal economy: why it matters. Entrepreneurship and Innovation, 12 (2), 85-93.

Byrne, B. 2010. Structural Equation Modelling with Amos: Basic Concepts, Applications, and Programming, $2^{\text {nd }}$ edn, London: Routledge

Castells, M., and Portes, A., 1989. World Underneath: The Origins, Dynamics, and Effects of the Informal Economy. In Portes, A., Castells, M., and Benton, L., Eds. The Informal Economy: Studies in Advanced and Less Advanced Developed Countries. Baltimore: John Hopkins.

Chen, M. 2012. The Informal Economy: Definitions, Theories and Policies. WIEGO Working Paper No.1, available online at: www.wiego.org, (accessed on 30/10/2013)

Chen, M., 2007. Rethinking the Informal Economy: Linkages with the Formal Economy and the Formal Regulatory Environment. United Nations Working Paper 46, available online at: www.un.org/esa, (accessed on 10/09/2011).

Choi, J. and Thum, M. 2005. Corruption and the Shadow Economy. International Economic Review, 46, 817-

De Soto, H., 1989. The Other Path: the Economic Answer to Terrorism. London: Harper and Row.

Dell'Anno, R. 2007. The shadow economy in Portugal: an analysis with the MIMIC approach. $\underline{\text { Journal of }}$ Applied Economics, 10 (2), 253-277.

Dell'Anno, R., Halicioglu, F., 2010. An ARDL model of unrecorded and recorded economies in Turkey. Journal of Economic Studies, 37 (6), 627-646.

Devey, R., Skinner, C., and Valodia, I., 2006. Second Best? Trends and Linkages in the Informal Economy in South Africa. DPRU Working Paper 06/102. Durban, available online at: http://ssrn.com/abstract=982337, (accessed on 09/09/2011).

Dobson, S. and Ramlogan-Dobson, C. 2012. Inequality, corruption and the informal sector. Economic Letters, 115, 104-107.

Dreher, A., Kotsogiannis, C., and McCorriston, S., 2005. How do institutions affect corruption and the shadow economy? International Tax and Public Finance, 16 (6), 773-796.

Ferraira-Tiryaki, G., 2008. The informal economy and business cycles. Journal of Applied Economics, 11 (1), 91-117.

Gallaway, J. and Bernasek, A. 2002. Gender and informal sector employment in Indonesia. Journal of Economic Issues, XXXVI (2), June, 313-321.

Gallin, D. 2001. Proposition of trade unions and informal employment in time of globalisation. Antipode, 19 (4), 531-549. 
Gang, N. and Gangopadhyay, S. 1987. Welfare aspects of Harris-Todaro economy with underemployment and variable prices. The Developing Economics, 25 (3), 203-219.

Garcia-Bolivia, O. 2006. Informal economy: is it a problem, a solution or both? The perspective of the informal business. Law and Economics Papers, 1, 1-28.

Geertz, C. 1963. Old Societies and New States: The Quest for Modernity in Asia and Africa. Glencoe, IL: Free Press.

Gerxhani, K. 2004. The informal sector in developed and less developed countries: A literature survey. Public Choice, 120 (2), 267-300.

Giese, S. and Hoffman, G. 1999. Tax evasion and risky investments in an intertemporal context - an experimental study. Discussion Paper 153, Berlin: Humboldt University.

Giles, A. and Johnson, J. 2000. Taxes, risk-aversion, and the size of the underground economy: a nonparametric analysis with New Zealand data. Econometrics Working Paper 0006, Canada: Department of Economics, University of Victoria, Canada.

Hart, K. 2012. How the informal economy took over the world, available online at: http://thememorybank.co.uk/...-economy/, (accessed on 09/11/2012).

Henry, S. 1978. The Hidden Economy. London: Martin Robertson.

Hu, L. and Bentler, P. 1999. Cutoff criteria for fit indexes in covariance structure analysis: Conventional criteria versus new alternatives. Structural Equation Modelling, 6 (1), 1-55.

Hussmanns, R., 2004. Statistical definition of informal employment: guidelines endorsed by the seventeenth international conference of labour statisticians. Conference Paper, available online at: www.ilo.org, (accessed on $09 / 3 / 2013)$

ILO, 2002. Women and men in the informal economy: a statistical picture. Employment Sector Paper, Geneva: International Labor Office.

ILO., 1972. Employment, Incomes and Equality: A Strategy for Increasing Productive Employment in Kenya. Geneva: ILO.

Lemieux, T., Fortin, B. and Frechette, P. 1994. The effect of taxes on labour supply in the underground economy. The American Economic Review, 88 (1), 231-254.

Loayza, N. 1996. The economics of the informal sector: a simple model and some empirical evidence from Latin America. Carnegie-Rochester Conference Series on Public Policy, 45, 129-162.

Losby, J. and Edgcomb, E. 2002. Informal economy literature review. ISED Consulting and Research and The Aspen Institute, US. Available online at: http://www.ised.us/, (accessed on 09/2/2012).

Macias, J., and Cazzavillan, G., 2009. The dynamics of parallel economies. Measuring the informal sector in Mexico. Research in Economics, 63, 189-199.

Maligalig, D. and Guerrero, M. 2008. How Can We Measure The Informal Sector? Paper presented at the Phillipine Statistical Association, Inc. available online: www.pdfio.net (accessed on the 12/03/2012).

Maloney, F., 2004. Informality Revisited. World Development, 24 (10), 1611-1619.

Marcelli, A., Pastor, M. and Joassert, M. 1999. Estimating the effect of informal economic activity: evidence from Los Angeles Count. Journal of Economic Issues, 33, 579-607

Moser, N., 1978. Informal sector or petty commodity production? Dualism or independence in urban development? World Development, 6, 1041-1064.

Myanmar, 2009. 2009 Informal Sector Survey Questionnaire. A publication of the Ministry of National Planning and Economic Development, Central Statistical Organisation, Myanmar.

Neuwirth, R. 2011. The Shadow Superpower, available online at: http://www.foreignpolicy.com/articles/2011.../black_market, (accessed on 30/01/2012).

NPC, 2006. Population Distribution by Age and Sex; Age, Sex and Marital Status: 2006 Census Priority Tables Vol.4; Vol.5. Available at: population.gov.ng/.../censuses.

Onuba, I. and Oyetunyi, A. 2014. 'Nigeria now Africa's biggest economy, overtakes S'Africa' 7 April 2014, www.punchng.com/news/nigeria-now-africa-biggest-economy-overtakes-safrica../, (8 April 2014)

Persson, A. and Malmer, H. 2006. Purchasing and Performing Informal Employment in Sweden: Part 1, Results from Various Studies. Malmo: Skatterverket.

Portes, A., Castells, M., and Benton, L., 1989. The Informal Economy: Studies in Advanced and Less Developed Countries, eds. Baltimore: John Hopkins University Press.

Reddy, M., Naidu, V. and Mohanty, M. 2003. The Urban Informal Sector in Fiji. Results from a Survey. $\underline{A}$ Journal of Contemporary Fiji, 1, 1, 128-154.

Santos, M. 1973. Economic development and urbanization in underdeveloped countries: the two circuits of the urban economy and their spatial implications, in Moser, C.. 1978. Informal sector or petty commodity production: Dualism or dependence in urban development? World Development, 6 (9-10), 1041-1064. 
Sassen-Koob, S., 1989. New York City's informal economy. In A. Portes, M. Castells, and L., Benton (Eds.). the Informal Economy: Studies in Advanced and Less Developed Countries, Baltimore: Johns Hopkins Press.

Schneider, F. 2003. The development of the shadow economies and shadow labor force of 22 transition and 21 OECD countries. IZA Discussion Paper No. 514, Bonn: Institute for the Study of Labor.

Schneider, F. 1998. Stellt das Anwachsen der Schwarzarbeit eine wirtschaftspolitische Herausforderung dar? Einige Gedanken aus volkswirtschaftlicher Sicht. Linz, Mitteilungen des Instituts für angewandte Wirtschaftsforschung, IAW, I/98, 4-13.

Schneider, F. and Enste H. 2003. The Shadow Economy: An International Survey, Cambridge: Cambridge University.

Schneider, F. and Enste, D., 2000. Shadow Economies Around the World: Sizes, Causes, and Consequences. Journal of Economic Literature, 38 (1), 77-114.

Schneider, F., Braithwaite, V. and Reinhart, M. 2001. Individual behaviour in Australia's shadow economy: facts, empirical findings and some mysteries. Working Paper No. 19, Australia: Australian National University.

Schneider, F., Buehn, A., and Montenegro, C., 2010. Shadow Economies All over the World: New Estimates for 162 Countries from 1999 to 2007. World Bank Policy Research Paper 5356, available: wwwwds.worldbank.org/

Sethuraman, S., ed., 1988 The Urban informal sector in developing countries: employment, poverty, and environment, Geneva: International Labour Office.

Sethuraman, S. 1981. The role of the urban informal sector: Concepts, methodology and scope. In Sethuraman, S., ed, 1981. The Urban Informal Sector in Developing Countries; Employment, Poverty and Environment. Geneva: International Labour Office.

Sethuraman, S. 1976. The urban informal sector: Concept, measurement and policy. International Labour Review. 114 (1), 69-81.

Singh, G and De Noble, A. 2003. Early retirees as the next generation of entrepreneurs. Entrepreneurship Theory and Practice, 27 (3), 207-226.

Snyder, K. 2004. Routes to the informal economy in New York's East village: crisis, economics and identity. Sociological Perspectives, 47 (2), 215-240.

Sookram, S., and Watson, P., 2008. Small-Business Participation in the Informal Sector of an Emerging Economy. Journal of Development Studies, 44 (10), 1531-1553.

Travers, A. 2002. Prospects for Enterprise : An Investigation into the Motivation of Workers in the Informal Economy. Evidence Paper 2, London: Community Links.

Verick, S., 2006. The Impact of Globalisation on the Informal Sector in Africa. Conference Papers, available online at: www.iza.org/conference_files/worldb2006/, (accessed on 10/07/2012).

Williams, C. 2013. Tackling Europe's Informal Economy: A Critical Evaluation of the Neo-liberal Deregulatory Perspective. Journal of Contemporary European Research, 9, (2), 261-278

Williams, C. 2006. Evaluating the magnitude of the shadow economy: a direct survey approach. Journal of Economic Studies, 33 (5), 369-385.

Williams, C. and Nadin, S. 2010. Entrepreneurship and the informal economy: an overview. Journal of Development Entrepreneurship, 15 (4), 361-378.

Williams, C. and Round, J. 2010. Spatial variation in the character of off-the-books entrepreneurship: study from contrasting districts in Moscow. International Journal of Entrepreneurship and Small Business, 10 (2), 287-301.

Williams, C. and Round, J. 2009. Out of the margins: Re-theorizing the role of the informal economy in Ukraine. International Journal of Economic Perspectives, 3 (1), 45-58.

World Bank, 2013. Nigeria: Country at a Glance. Available at: worldbank.org/en/country/Nigeria (10/02/2014)

Appendix

Table A1: Respondents' perceptions on various indicators

\begin{tabular}{lllllllll}
\hline & $\mathrm{A}$ & $\mathrm{B}$ & $\mathrm{C}$ & $\mathrm{D}$ & $\mathrm{E}$ & $\mathrm{F}$ & $\mathrm{G}$ & $\mathrm{H}$ \\
\hline Strongly Agreed & 17.9 & 12.7 & 20.4 & 5.0 & 29.3 & 10.2 & 7.8 & 19.6 \\
\hline Agreed & 16.4 & 31.3 & 32.7 & 6.9 & 43.7 & 19.4 & 18.0 & 47.5 \\
\hline Neither & 9.5 & 23.9 & 16.3 & 8.9 & 12.2 & 15.7 & 16.7 & 15.0 \\
\hline Disagreed & 32.2 & 26.8 & 18.6 & 27.5 & 9.1 & 31.2 & 35.2 & 10.5 \\
\hline Strongly Disagreed & 24.0 & 5.3 & 12.0 & 51.8 & 5.7 & 23.6 & 22.2 & 7.4 \\
\hline Total & 100 & 100 & 100 & 100 & 100 & 100 & 100 & 100 \\
\hline Total responses & 391 & 377 & 392 & 597 & 583 & 581 & 599 & 592 \\
\hline
\end{tabular}


Note: A - If government can provide job for every Nigerian, nobody would participate in informal activities; B Government regulation of businesses is too much; C - It is very difficult to do business in the informal sector without giving bribes to some-law enforcement agents; D - Government should discourage the informal sector as it is harmful to the Nigerian economy; E - Informal sector activities are good for Nigeria's economy; F - People are poor because they work or do business in the informal sector as participants are disadvantaged; $G$ - Government does not have sufficient revenue because informal workers do not pay tax; $\mathrm{H}$ - Informal sector helps people that are poor to overcome poverty in Nigeria.

Table A2: Biggest problems \& challenges of the informal economy

\begin{tabular}{|c|c|c|c|c|}
\hline $\begin{array}{l}\text { What do you know or think is the biggest } \\
\text { problem faced by the informal sector? }\end{array}$ & $\%$ & $\begin{array}{l}\text { Challenges confronting } \\
\text { participants }\end{array}$ & $1^{\mathrm{st}}$ & $2^{\text {nd }}$ \\
\hline $\begin{array}{l}\text { inadequate finance, high interests, inaccessible } \\
\text { loans }\end{array}$ & 43.2 & Supply of raw materials & 9.8 & 4.9 \\
\hline $\begin{array}{l}\text { record keeping (poor, none), management } \\
\text { capacity, skills gap }\end{array}$ & 6 & $\begin{array}{l}\text { Access to land, space for } \\
\text { business }\end{array}$ & 6.2 & 13.4 \\
\hline job security, irregularity, high risk, poverty & 9.3 & $\begin{array}{l}\text { Lack of adequate machines, } \\
\text { equipment }\end{array}$ & 4.1 & 18.3 \\
\hline government unsupportive \& irresponsible & 13.1 & Difficult to get loan & 17.5 & 7.3 \\
\hline excessive tax & 6.0 & Lack of customers & 18 & 11 \\
\hline Corruption (employee, govt., its officials) & 2.2 & Too much competition & 24.2 & 20.7 \\
\hline $\begin{array}{l}\text { overregulation, unfriendly policies \& } \\
\text { environment, }\end{array}$ & 2.2 & $\begin{array}{l}\text { Organisation, management } \\
\text { difficulty }\end{array}$ & 3.1 & 4.9 \\
\hline high competition, little revenue \& patronage & 9.8 & Too much govt. control, taxes & 8.2 & 7.3 \\
\hline \multirow[t]{2}{*}{$\begin{array}{l}\text { Others(poor electricity, road, insecurity- } \\
\text { inadequate infrastructure, mkt. access) }\end{array}$} & 4.4 & Too little revenue & 8.8 & 9.8 \\
\hline & & Others & & 2.4 \\
\hline Total & 100 & Total responses & 100 & 100 \\
\hline
\end{tabular}

